\title{
World Power Forsaken
}

With the restoration of full sovereignty, we Germans have gained not only more freedom of action but also more responsibility. That is how our international partners see it. They expect united Germany to do justice to this new role. It has absolutely nothing to do with unilateral efforts or even power ambitions.

- German Chancellor Helmut Kohl

We are not a world power, and we have neither the capability nor the desire to be one.

-Former Chancellor Helmut Schmidt

The newly-won latitude of united Germany will most certainly not be used for a new policy of power politics.

-Hans-Dietrich Genscher (German Foreign Minister until May 1992)

Germany will never become a world power.

-Klaus Kinkel (German Foreign Minister since May 1992)

We are not a world power.

—Volker Rühe (German Defense Minister since April 1992) 
